\title{
The Effect of Revaluation, Inventory and Lease of State-Owned Assets on Optimization of Non-Tax State Revenue in Indonesia
}

\author{
Tifany Citrayantie ${ }^{1}$, Mediaty $^{2}$, Aini Indrijawati ${ }^{3}$ \\ 1,2,3 Faculty of Economics and Business, Hasanuddin University, Makassar, Indonesia.
}

Corresponding Author: Tifany Citrayantie

\begin{abstract}
The Republic of Indonesia's state revenue is used for the state budget to achieve public welfare, where one component of state revenue is from non-tax state revenue. The government maximizes the use of state-owned assets to optimize non tax state revenue, so that it can support tax revenues in financing the state. The purpose of the study was to determine and analyze the effect of partially or simultaneously the revaluation, inventory, and lease of stateowned assets on the optimization of non-tax state revenue. This research is a quantitative research, using a survey method that uses an instrument in the form of a questionnaire. The conclusions are revaluation, inventory, and lease of state-owned assets partially positive and significant effect on the optimization of non-tax state revenue; and the revaluation, inventory and lease of state-owned assets simultaneously have a positive and significant effect on the optimization of non-tax state revenue.
\end{abstract}

Keywords: Non-Tax State Revenue, Revaluation, Inventory, Lease, State-Owned Assets

\section{INTRODUCTION}

The Government of the Republic of Indonesia (RI) needs state revenues to be able to finance development and improve the welfare of the people, as well as to handle the COVID-19 pandemic that occurred in Indonesia. RI's state revenue consists of revenues from taxes, non-tax state revenues and grants. Tax revenue is still the largest state revenue to date.
However, in the last few years, especially in 2020, where the impact of the COVID-19 pandemic was felt so massively due to government policies in operational restrictions, so that the realization of tax revenues did not reach the target. Therefore, the government seeks to optimize non-tax state revenue. Non-tax state revenue itself is a levy paid by individuals or entities by obtaining direct or indirect benefits for services or utilization of resources and rights obtained by the state (Law RI Number 9, 2018). The composition of state revenue realization in 2020 shows that nontax state revenue contributes $6.75 \%$ of state revenue, and this is the second largest state revenue after tax revenue $(75.76 \%)$. The fact is that the achievement of non-tax state revenue in 2020 is 343.8 trillion Rupiah, exceeding the target set in Presidential Regulation Number 72/2020 "Amendments to Presidential Regulation Number 54 of 2020 concerning Changes in Posture and Details of the 2020 State Revenue and Expenditure Budget", showing a positive performance in supporting state revenues, where the non-tax state revenue's target is targeted at 294.1 trillion Rupiah (Presidential Decree Number 72, 2020). So, from these data it can be said that non-tax state revenue contributes to the APBN from year to year which continues to increase, only in 2020 it has decreased due to the impact of the COVID-19 pandemic from the previous year, where in 2019 non-tax state revenues was 409.0 trillion Rupiah. But, 
non-tax state revenue is still able to support tax revenues in financing the state. Based on the Law on non-tax state revenue, it states that the objects that are the source of nontax state revenue include: utilization of natural resources; service; the management of state assets is separated; management of state-owned assets; fund management; and other state rights. In this study, researchers focused on the sources of non-tax state revenue obtained from state-owned assets.

The Government of the Republic of Indonesia first compiled the Financial Report of the Central Government of the Republic of Indonesia (LKPP) in 2004, RI's LKPP received a "disclaimer" opinion by BPK RI. One of the reasons is that BPK RI cannot believe in the fairness of the presentation of the value of fixed assets. Therefore, the government decided to form a State-Owned Assets Control Team to be able to carry out an inventory and assessment of state-owned assets in 2007 2008 on state-owned assets which obtained up to 2004. Ten years later, in 2017-2018, the Government of the Republic of Indonesia carried out a revaluation of stateowned assets which obtained up to 2015. The Government did this because in 10 years since the inventory and assessment in 2007-2008 was carried out, of course the value of assets (state-owned assets) would be experiencing changes, especially fixed assets. It can be said that revaluation is a step in renewing the value of an asset (stateowned assets) to its true value and reflecting its value at the time of revaluation (Media Kekayaan Negara, 2020). Yuniarto (2020) also stated the importance of revaluing assets because in order to increase the accuracy of the value of state-owned assets in the Central Government Financial Report (LKPP). After the revaluation of stateowned assets in 2017-2018, there was a very significant increase in the value of fixed assets, especially in land assets where the increase was Rp. 3,547,106,425,456,425,00 equivalent to a $348.22 \%$ increase in the value of land assets in 2018. Likewise, Buildings had an increase in value after the revaluation of state-owned assets of $\mathrm{Rp}$. $78,414,561,729,795,00$ equivalent to a 27.32\% increase (LKPP, 2020). Yuniarto (2020) said that it must be realized that if asset revaluation is only temporary and cannot be valid forever (only valid for a few years), then the financial statements/balance sheet revaluation will be affected by annual inflation and changes in exchange rates. Therefore, it is important for the government to carry out a revaluation within a certain period of time, so that changes in the value of state-owned assets caused by inflation and changes in currency exchange rates can be updated.

Inventories have also been carried out by the government in 2007-2008 and 2017-2018 so that LKPP can get a good opinion from BPK RI. Ministry of Finance of Republic of Indonesia (PMK) Number 181 of 2016 explains that inventory is one of the scopes of State-Owned Assets Administration, it is stated in the PMK that the scope of activities of State-Owned Assets Administration, includes: 1). Bookkeeping; 2). inventory; and 3). reporting. It is important to make an inventory of state-owned assets so that data on state-owned assets can reflect the existence, condition and amount of stateowned assets in accordance with the facts on the ground. Inventory is also carried out on idle state-owned assets. Idle state-owned assets' the Government of the Republic of Indonesia amounted to Rp. 74,778,884,370,00 in the 2019 Fiscal Year and increased in the 2020 Fiscal Year to Rp. 75.042.226.330,00 (LKPP, 2020). According to the researcher, this amount is a considerable nominal for idle state-owned assets which can be used as potential for non-tax state revenue, and these funds will of course be able to increase the income of State Revenue which is used for the welfare of the community.

In this study, researchers focused on sources of non-tax state revenue obtained from the management of state-owned assets. Management of state-owned assets is an activity related to the use, utilization, and 
transfer of all state-owned assets purchased or obtained at the expense of the state budget (APBN) or derived from other legitimate acquisitions. The management of state-owned assets which can provide nontax state revenue is the use of state-owned assets, namely the utilization of state-owned assets which is not used for the implementation of the duties and functions of the Ministry/Agency/work unit (idle) without changing its ownership status (Government Regulation Number 28 of 2020, 2020). Government Regulation Number 28 of 2020 also states that the form of utilization of state-owned assets consists of: 1). rent; 2). lease; 3). utilization cooperation; 4). wake up to handover or wake up handover (BGS/BSG); 5). cooperation in providing infrastructure (KSPI); or limited cooperation for infrastructure financing (KETUPI). According to the Regulation of the Minister of Finance of the Republic of Indonesia Number 115/2020 concerning Utilization of State-Owned Assets, what is meant by lease is the use of state-owned assets by other parties within a certain period of time and receiving cash rewards and the cash will be deposited into the state treasury. The trend of non-tax state revenues for the use of idle state-owned assets from 2016-2020 received by the state continues to increase, it can be seen in Table I.1. Although only in 2018, the increase was very significant because in that year there was non-tax state revenue from the use of state-owned assets on state assets which is paid directly for 50 years. However, if we look at the general trend, there is an increase in non-tax state revenue from the idle utilization of state-owned assets. In 2020, the use of state-owned assets did not decrease significantly compared to the previous year, considering that in 2020 the impact of the COVID-19 pandemic had already been felt.

State-owned assets which has been updated according to its fair value after the revaluation of state-owned assets, and an inventory of idle state-owned assets has been carried out, will affect the calculation of the leasing value of the state-owned assets, where The fair value of the asset is one of the factors in calculating the amount of the lease. The lease amount is calculated from the multiplication between the lease principal rate and the lease adjustment factor. The principal lease rate is determined from the fair value of the lease, while the lease adjustment factors include: the type of business activity of the lessee and the periodicity of the lease.

TABLE 1. Non-tax revenue for the use of state-owned assets 2016-2020

\begin{tabular}{|l|l|}
\hline Fiscal year & Amount (Rp) \\
\hline 2016 & $343,438,059,926,00$ \\
\hline 2017 & $505,472,586,764,00$ \\
\hline 2018 & $1,575,471,215,636,00$ \\
\hline 2019 & $522,960,362,436,00$ \\
\hline 2020 & $513,738,203,370,00$ \\
\hline
\end{tabular}

According with the above, it is necessary to conduct research on the factors that influence the optimization of non-tax state revenues on the use of state-owned assets. There are several studies that have been conducted previously related to the lease of state-owned assets on non-tax state revenues. The research conducted by Putri (2020), Sadil (2018), and Ratna (2017) is a qualitative research conducted regarding the lease of state-owned assets on non-tax state revenues, and is carried out as a case study only on one KPKNL. Meanwhile, the research conducted by Yanti, et al (2020) used quantitative research methods in the Work Unit in Palembang City and the respondents were state-owned assets users. This study is a replication study of the research that has been carried out by Yanti, et al (2020). However, there are some differences between this study and the research conducted by Yanti, et al (2020), namely: 1) replacing the variables "management of state-owned assets " and "utilization of state-owned assets " in the research of Yanti, et al (2020), into variables "lease of state-owned assets" in this study, because this researcher focuses more on the management and utilization intended in this study; 2). Yanti's research, et al (2020) chose state-owned assets users at the Palembang KPKNL as respondents, 
while in this study the respondents in distributing the questionnaire were the stateowned assets managers at the Regional Office of DJKN Sulseltrabar and several KPKNL in South Sulawesi Province, Southeast Sulawesi Province, West South Sulawesi, and Jakarta.

The purpose of this study based on the formulation of the problem above is to determine and analyze: 1 ). The effect of the revaluation of state-owned assets on the optimization of non-tax state revenues; 2). The effect of the inventory of state-owned assets on optimizing non-tax state revenue; 3 ). The effect of the lease of state-owned assets on the optimization of non-tax state revenues; 4 . The simultaneous effect of revaluation, inventory, and lease of stateowned assets on the optimization of non-tax state revenues.

\section{LITERATURE REVIEW}

The Grand Theory that underlies this research is the Stewardship Theory. Stewardship theory is a theory that argues that managers will provide effective action or action against existing structural situations (Donaldson \& Davis, 1991). Stewardship theory says that managers focus on achieving organizational goals, where managers strive to continuously improve their performance so that organizational goals are achieved properly. Managers do not focus on self-interest or individual interests, but are much broader than that, namely the interests of the organization. Therefore, managers will continue to focus on achieving the interests of the organization, where managers will try to make a good system in high performance, with the hope that organizational goals are achieved, so that the organization and all those in the system also feel satisfied with the results. In Government, the theory can also be applied. It is clear that the goals of the Government, both regional and central, have the same goal, namely the welfare of the people. Where at every level of office in the Government will strive to provide high performance in order to achieve this goal (public welfare). The interests that become the main focus are the interests of the wider community, not for personal interests, let alone group interests. This is supported by research by Morgan, et al (1996) that the "middle manager" in the government, is more serving (steward) than as an agent in achieving government goals (public welfare). In this study, the "manager" in the government is the state-owned assets manager, where the "managers" continue to strive to maximize the utilization of idle state-owned assets that has been recorded and updated after the inventory and revaluation in order to continue to work and generate non-tax state revenue.

According to Law Number 9/2018 concerning Non-Tax State Revenue, explains that what is meant by non-tax state revenue is a levy paid by an individual or entity where the individual or entity can benefit from services or utilization of resources and rights obtained by the state either directly or indirectly, based on regulations legislation, which becomes the Central Government's revenue in addition to revenues received by the state from taxes and grants, where the non-tax state revenue is then managed in the APBN mechanism. In this study, the focus in optimizing nontax state revenue is the utilization of stateowned assets in the form of lease of stateowned assets which is carried out by an inventory and revaluation of the previous idle state-owned assets, so that the idle state-owned assets data that is leased out is up to date.

Government Regulation Number 28/2020 explains that state-owned assets are all state-owned assets purchased or obtained from APBN expenditures or from other legitimate acquisitions. Other legitimate acquisitions such as grants/donations, implementation of agreements/contracts, and others. Meanwhile, the Minister of Finance Regulation Number 71/2016 explains that what is meant by idle stateowned assets is state-owned assets that is not used to carry out the duties and functions of Ministries/Agencies in the form 
of land and/or buildings that are not used for the purpose of carrying out the duties and functions of Ministries/Agencies.

Revaluation of state-owned assets is carried out so that the government has a fair value for state-owned assets. Based on the Stewardship Theory where the goals of the company/organization are primary and above personal goals, of course the government (both state-owned assets managers and state-owned assets users) will work together to be able to succeed in the revaluation carried out in 2017 - 2018. Research conducted by Yanti, et al (2020) shows that the research results are not significant on the effect of the revaluation of state-owned assets on the optimization of non-tax state revenue. However, there are no other studies that have examined the effect of revaluation on the optimization of non-tax state revenue other than that conducted by Yanti, et al (2020). However, asset revaluation has been shown to have a significant impact on future operating performance, especially in relation to income (Aboody, et al (1999) and Barley, et al (2007). Therefore, it is deemed necessary by the Government of Indonesia to carry out asset revaluation so that assets are recorded at their fair value and asset management is better (Yuniarto, 2020). Based on the above framework, the researcher formulates the following hypothesis: $\mathrm{H} 1$ = Revaluation of State-Owned Assets Affects the Optimization of Non-Tax State Revenue.

The Minister of Finance Regulation Number 107/2019 states that inventory is an activity related to data collection, recording, and reporting of state-owned assets data collection results. Stewardship theory believes that organizations (in this case the government) will do their best to achieve organizational goals, one of which is by providing services to those in need in order to achieve organizational goals. The inventory of state-owned assets is the initial stage so that the government can use stateowned assets for lease. State-owned assets data collection must be carried out properly, therefore assistance from state-owned assets managers to state-owned assets users is very important. The research conducted by Yanti, et al (2020) showed that the results of the study were not significant on the effect of the inventory of state-owned assets on the optimization of non-tax state revenue. Research conducted by Putri (2020) qualitatively by interviewing informants at the Surabaya KPKNL, showed that the inventory of state-owned assets was still not optimal with an inefficient database, but it was important to carry out an inventory so that the government knew about updated data on managed state-owned assets. Therefore, based on the above framework, the researcher formulates the following hypothesis: H2 = Inventory of State-Owned Assets Affects the Optimization of Non-Tax State Revenue.

Government Regulation Number 28/2020 and The Minister of Finance Regulation Number 115/2020 explain that leasing is an activity of utilizing stateowned assets by other parties for a certain period of time, and receiving cash rewards for leasing state-owned assets. Stewardship theory argues that individuals in organizations will try to give the best of themselves in order to achieve organizational goals. Organizational goals take precedence over individual goals. In this case, the organization's goal is to optimize non-tax state revenue through state-owned assets' leases so that state revenues are able to finance the needs of the state in the welfare of the community. Putri (2020), Sadil, et al (2018), and Ratna (2017) conducted research using qualitative methods with the results of the research being that there were many factors that caused the less than optimal utilization of leases of state-owned assets in increasing non-tax state revenue. This is different from the research conducted by Yanti, et al, (2020) which uses quantitative research methods, where the research concludes that the use of leases of state-owned assets has a positive effect on non-tax state revenue. Therefore, based on the above framework, the researcher formulates the following 
hypothesis: $\mathrm{H} 3$ = Lease of State-Owned Assets Affects the Optimization of Non-Tax State Revenue.

Stewardship theory explains that managers will ensure that company goals can be achieved in ways that are deemed necessary. In this study, the government as a manager, will take various ways that are not against the law and are regulated in accordance with existing regulations so that the government's goals can be achieved in the welfare of the community. One of them is by conducting an inventory and revaluation of state-owned assets that can be leased so that it can generate non-tax state revenue. Based on the research of Yanti, et al (2020) who concluded that the revaluation, inventory and lease of stateowned assets simultaneously affect the optimization of non-tax state revenue, the researchers formulate the following hypothesis: H4 = Revaluation, Inventory, And Lease of State-Owned Assets Have Simultaneous Effect on Optimization of Non-Tax State Revenue.

\section{MATERIALS \& METHODS}

This research is a quantitative research. This study uses a survey method, where the survey method is a method used to collect information or data about people, events or situations using instruments in the form of questionnaires, interviews, and/or structured observations (Sekaran \& Bougie, 2016). This study uses a sampling technique with purposive sampling technique method. The sampling technique purposive sampling is a sampling technique by determining the sample based on certain considerations (Sugiyono 2018). Therefore, the samples in this study were employees in the State and Wealth Management Section (PKN) and the Appraisal Section at the DJKN Regional Office of South Sulawesi; KPKNL Makassar; KPKNL Pare-Pare; KPKNL Palopo; KPKNL Kendari; KPKNL Mamuju; and KPKNL Jakarta II.

The researcher uses the following variables: the dependent variable (optimization of non-tax state revenues), the independent variable (revaluation, inventory, and lease of state-owned assets. The research instrument used in this study was a questionnaire, where the questionnaire was prepared based on predetermined indicators. This questionnaire will use a Likert scale, which is a scale designed to explain how the opinion of respondents on a question or statement. The research instrument will be tested for validity and reliability first. Then, the data will be tested for classical assumptions and multiple linear regression testing.

The equations used for the multiple linear regression model are:

$\mathrm{Y}=\mathrm{a}+\mathrm{b} 1 \mathrm{X} 1+\mathrm{b} 2 \mathrm{X} 2+\mathrm{b} 3 \mathrm{X} 3+\mathrm{e}$

$\mathrm{Y}=$ Dependent Variable (Optimization of Non-Tax State Revenue)

$\mathrm{a}=\quad$ Constant Coefficient

b1, b2, b3 = Regression Coefficient

$\mathrm{X} 1=$ Revaluation of State-Owned Assets

$\mathrm{X} 2=$ Inventory of State-Owned Assets

X3 $=$ Lease of State-Owned Assets

$\mathrm{e}=$ error term

\section{RESULT}

The results of the statistical test for the first hypothesis (H1) indicate that the revaluation of state-owned assets has a positive and significant effect on the optimization of non-tax state revenue. This is evidenced by the t-test value of 2.526 which is greater than the t-table of 1.988 , with a significance level of 0.013 which is smaller than the $5 \%$ alpha. A positive regression coefficient indicates that the higher the revaluation of state-owned assets, the higher the optimization of non-tax state revenue will be. It can be concluded that the first hypothesis (H1) is accepted.

The results of the statistical test for the second hypothesis (H2) indicate that the inventory of state-owned assets has a positive and significant effect on the optimization of non-tax state revenue. This is evidenced by the t-test value of 2.327 which is greater than the t-table of 1.988 , with a significance level of 0.022 which is smaller than the $5 \%$ alpha. A positive regression coefficient indicates that the 
higher the inventory of state-owned assets, the higher the optimization of non-tax state revenue. It can be concluded that the second hypothesis (H2) is accepted.

The results of the statistical test for the third hypothesis (H3) show that the lease of state-owned assets has a positive and significant effect on the optimization of non-tax state revenue. This is evidenced by the t-test value of 3.264 which is greater than the t-table of 1.988, with a significance level of 0.002 which is smaller than the $5 \%$ alpha. A positive regression coefficient indicates that the higher the lease of stateowned assets will increase the optimization of non-tax state revenue. It can be concluded that the third hypothesis (H3) is accepted.

Simultaneous statistical test results (Test F) show that the revaluation, inventory, and lease of state-owned assets simultaneously have a positive and significant effect on the optimization of non-tax state revenue. This is evidenced by the calculated $F$ test value of 36,780 which is greater than the $\mathrm{F}$ table of 2.70, with a significance level of 0.000 which is smaller than the $5 \%$ alpha. The results of statistical tests also show that the variables of revaluation, inventory and lease of stateowned assets simultaneously affect the optimization of non-tax state revenue by $57.1 \%$, while the remaining $42.9 \%$ is influenced by other variables. It can be concluded that the fourth hypothesis (H4) is accepted.

\section{DISCUSSION}

A positive regression coefficient indicates that the higher the revaluation of state-owned assets, the higher the optimization of non-tax state revenue will be. It can be concluded that the first hypothesis (H1) is accepted. The results of this test support the Stewardship Theory which explains that managers, in this case the manager is the government, will take steps that can make the government achieve its goals in the welfare of society. One of the steps taken by the government is to conduct a revaluation of state-owned assets so that the idle state-owned assets that can be utilized, has its fair value before being utilized and generates non-tax state revenue. However, this result is different from the research conducted by Yanti, et al (2020), where the results obtained are that revaluation of state-owned assets does not have a significant effect on the optimization of non-tax state revenue. Apart from the research conducted by Yanti, et al (2020), there has been no other research related to the effect of the revaluation of state-owned assets on the optimization of non-tax state revenues. Brown, et al (1992) agree that asset revaluation is important to do, so that the asset value presented represents a value that is close to its current value (fair value). Aboody, et al (1999) and Barley, et al (2007) stated that asset revaluation proved to have a significant impact on future operating performance, especially related to income.

A positive regression coefficient indicates that the higher the inventory of state-owned assets, the higher the optimization of non-tax state revenue. It can be concluded that the second hypothesis (H2) is accepted. The results of this test support the Stewardship theory which explains that the government as a manager, seeks to carry out an inventory of stateowned assets so that data on state-owned assets is up to date. This is one of the steps taken by the government so that it can record idle state-owned assets so that the idle state-owned assets can be used by leasing it out, in order to generate non-tax state revenue. However, this result is different from the research conducted by Yanti, et al (2020), where the results obtained are that the inventory of stateowned assets does not have a significant effect on the optimization of non-tax state revenue. Although, there has been no other quantitative research that examines the effect of an inventory of state-owned assets on optimizing non-tax state revenue, there are several qualitative studies that have been conducted previously, and state that an 
inventory of state-owned assets is important to do. Kaganova (2010) states that good asset management can generate financial benefits that have an impact on state revenues. Inventory is part of asset management activities, so it can be said that the research conducted by Kaganova (2010) is in line with the results of this study. Research conducted by Ratna (2017), Hariyanto and Narsa (2018), Putri (2020), and Gaffar et al (2020) argues that it is important to carry out an inventory, especially the inventory of state-owned assets, including idle state-owned assets, so that state-owned assets can be properly recorded, maintained, secured from abuse, and can be utilized.

A positive regression coefficient indicates that the higher the lease of stateowned assets will increase the optimization of non-tax state revenue. It can be concluded that the third hypothesis (H3) is accepted. These results support the research conducted by Yanti, et al (2020), where the results obtained are that the use of stateowned assets through the leasing mechanism has a significant effect on the optimization of non-tax state revenue. The results of this test support the Stewardship theory which explains that the government as a manager seeks to achieve organizational goals, namely the welfare of society. In this case, the government makes use of idle state-owned assets so that it can generate additional income for the state through leases of state-owned assets which generate non-tax state revenue. Although, there has been no other quantitative research that specifically examines the effect of lease of state-owned assets on the optimization of non-tax state revenues, research conducted by Ratna (2017), Sadil, et al (2018), and Putri (2020) stated that the results of the research interviews conducted agreed that the use of state-owned assets through the leasing mechanism had the potential to generate more optimal non-tax state revenues. However, their research also found that in practice they still face obstacles so that the utilization of state- owned assets with the leasing mechanism has not been optimal.

The results of statistical tests also show that the variables of revaluation, inventory and lease of state-owned assets simultaneously affect the optimization of non-tax state revenue by $57.1 \%$, while the remaining $42.9 \%$ is influenced by other variables. It can be concluded that the fourth hypothesis (H4) is accepted. The results of this study are supported by research conducted by Yanti, et al (2020) that simultaneously inventory, revaluation, management and utilization of state-owned assets affect the optimization of non-tax state revenues. However, there are no other studies that have conducted research with the same variable testing as this study and the research conducted by Yanti, et al (2020).

\section{CONCLUSION}

Based on the results of statistical testing on the hypotheses and discussions that have been stated previously, related to the effect of revaluation, inventory, and lease of state-owned assets on the optimization of non-tax state revenues, it can be concluded as follows: 1). The revaluation of state-owned assets has a positive and significant effect on the optimization of non-tax state revenues, the first hypothesis (H1) is accepted; 2). The inventory of state-owned assets has a positive and significant effect on the optimization of non-tax state revenues, the second hypothesis (H2) accepted; 3). The lease of state-owned assets has a positive and significant effect on the optimization of non-tax state revenue, the third hypothesis (H3) is accepted; 4). Based on the results of the $\mathrm{F}$ test, it is proven that the revaluation, inventory, and lease of state-owned assets simultaneously affect the optimization of non-tax state revenues. So, the fourth hypothesis (H4) is accepted.

The theoretical implication of the findings of this study is that this research supports the Stewardship theory, where the government in this case as a "manager" who 
seeks to achieve organizational goals, namely the goal of the state in the welfare of society, will seek to prioritize state goals compared to personal goals. In achieving this goal, the government takes steps that are deemed necessary to be carried out, according to the results of this study, namely, either partially or simultaneously, revaluation, inventory, and lease of stateowned assets have a significant effect on the optimization of non-tax state revenues. The managerial implication of the findings of this study is that the results of this study can be used as references, inputs, and studies regarding the revaluation, inventory, and lease of state-owned assets in order to optimize non-tax state revenues.

This study has several limitations that may affect the results obtained, as follows: 1. This study had a total of 87 respondents, which of course is still insufficient to describe the actual situation; 2. Most of the questionnaires were distributed via a link that could be filled out directly by the respondent without any assistance from the researcher, so that differences in perception might occur; 3. Restrictions on community activities during the COVID-19 pandemic make it difficult for researchers to add sites to conduct research. Some suggestions for future research include the following: 1). Adding other independent variables to test the effect on the optimization of non-tax state revenues; 2). Adding research samples so that research results can be generalized to the territory of Indonesia; 3). Provide assistance when filling out the questionnaire to minimize bias that may occur due to differences in perception.

\section{ACKNOWLEDGMENT}

This research was supported by the Indonesian Endowment Fund for Education (LPDP RI).

\section{Conflict of Interest: None}

Source of Funding: None

\section{REFERENCES}

1. Aboody, David, Mary E. Barth, and Ron Kasznik. 1999. "Revaluations of Fixed Assets and Future Firm Performance : Evidence from The UK." Journal of Accounting and Economics 149-178.

2. Barley, Benzion, Dov Fried, Joshua Rene Haddad, and Joshua Livnat. 2007. "Reevaluation of Revaluations : A CrossCountry Examination of the Motives and Effects on Future Performance." Journal of Business Finance \& Accounting 1025-1050.

3. Brown, Philip, H.Y. Izan, and Alfred L. Loh. 1992. "Fixed Asset Revaluations and Managerial Incentives." ABACUS 36-57.

4. DJKN, Kementerian Keuangan. 2020. "Media Kekayaan Negara, Edisi No. 36."

5. Donaldson, Lex, and James H. Davis. 1991. "Stewardship Theory or Agency Theory: CEO Governance and Shareholder Returns." Australian Journal of Management 16: 4964.

6. Gaffar, Ismail, Basri Hasanuddin, and Andi Kusumawati. 2017. "Pengaruh Inventarisasi Aset, Sumber Daya Manusia Terhadap Optimalisasi Aset dengan Sistem Informasi Sebagai Variabel Moderasi." Jurnal Analisis 164-172.

7. Hariyanto, Eko Budi, and I Made Narsa. 2018. "Strategic Assets Management : Fokus Pemanfaatan Aset Negara dengan Pendekatan Resource Based View (RBV)." AKTSAR : Jurnal Akuntansi Syariah 113129.

8. Kaganova, Olga. 2010. Government Management of Land and Property Assets:Justification for Engagement by the Global Development Community. Urban Institute Center on International Development and Governance.

9. Morgan, Douglas, Kelly G Bacon, Ron Bunch, Charles Cameron, and Robert Deis. 1996. "What Middle Managers Do In Local Government: Stewardship of The Public Trust And Limits Of Reinventing Government." Public Administration Review 56 (4).

10. Putri, Feldha Shastiana. 2020. "Optimalisasi Pemanfaatan Sewa Barang Milik Negara untuk Meningkatkan Penerimaan Negara Bukan Pajak." Jurnal Ilmu dan Riset Akuntansi 1-18.

11. Ratna. 2017. "Studi tentang Pelaksanaan Sewa Barang Milik Negara (BMN) dalam Mengoptimalisasi Penerimaan Negara di 
Tifany Citrayantie et.al. The effect of revaluation, inventory and lease of state-owned assets on optimization of non-tax state revenue in Indonesia.

Kantor Pelayanan Kekayanaan Negara dan Lelang (KPKNL) Samarinda." eJournal Administrasi Negara 5909-5921.

12. Sadil, Cecen A., Dede F. Mahyudin, Wanly Harikase, and Jenny Morasa. 2018. "Ipteks Pelaksanaan Sewa Barang Milik Negara pada Kantor Pelayanan Kekayaan Negara dan Lelang (KPKNL) Manado." Jurnal Ipteks Akuntansi Bagi Masyarakat 214-217.

13. Sekaran, Uma, and Roger Bougie. 2016. Research Methods for Business : A Skill Building Approach (Seventh Edition). United Kingdom: John Wiley \& Sons.

14. Sugiyono. 2018. Metode Penelitian Bisnis : Pendekatan Kuantitatif, Kualitatif, Kombinasi, dan R\&D. Bandung: Penerbit Alfabeta.

15. Yanti, Ermi, Didik Susetyo, and Yulia Saftiana. 2020. "The Effect of Inventory Appraisal and Revaluation of State Property on the Optimization of Non-Tax State Revenue." Finance : Theory and Practice 110-117.

16. Yuniarto, Agung. 2020. "Melihat Perlunya Pemerintah Melakukan Program Revaluasi Aset Barang Milik Negara." Jurnal Pajak dan Keuangan Negara 1-8.

17. 2016. "Peraturan Menteri Keuangan Republik Indonesia Nomor 71/PMK.06/2016 tentang Tata Cara Pengelolaan Barang Milik Negara yang Tidak Digunakan untuk Menyelenggarakan Tugas dan Fungsi Kementerian Negara/Lembaga."

18. 2016. "Peraturan Kementerian Keuangan Nomor 181 Tahun 2016 tentang Penatausahaan Barang Milik Negara."
19. 2017. "Laporan Keuangan Pemerintah Pusat Republik Indonesia Tahun 2016 (Audited)."

20. 2017. "Peraturan Presiden RI Nomor 75 Tahun 2017 tentang Penilaian Kembali Barang Milik Negara/Daerah."

21. 2018. "Laporan Keuangan Pemerintah Pusat Republik Indonesia Tahun 2017 (Audited)."

22. 2018. "Undang-Undang Republik Indonesia Nomor 9 Tahun 2018 tentang Penerimaan Negara Bukan Pajak."

23. 2019. "Laporan Keuangan Pemerintah Pusat Republik Indonesia Tahun 2018 (Audited)."

24. 2019. "Peraturan Menteri Keuangan Republik Indonesia Nomor 107/PMK.06/2019 tentang Perubahan Kedua atas Peraturan Menteri Keuangan Nomor 118/PMK.06/2017 tentang Pedoman Pelaksanaan Penilaian Kembali Barang Milik Negara."

25. 2020. "Peraturan Menteri Keuangan Republik Indonesia Nomor 115/PMK.06/2020 tentang Pemanfaatan Barang Milik Negara."

26. 2020. "Peraturan Pemerintah Republik Indonesia Nomor 28 Tahun 2020 tentang Perubahan atas Peraturan Pemerintah Nomor 27 Tahun 2014 tentang Pengelolaan Barang Milik Negara/Daerah."

27. 2020. "Laporan Keuangan Pemerintah Pusat Republik Indonesia Tahun 2019 (Audited)."

How to cite this article: Tifany Citrayantie, Mediaty, Aini Indrijawati. The effect of revaluation, inventory and lease of state-owned assets on optimization of non-tax state revenue in Indonesia. International Journal of Research and Review. 2021; 8(12): 587-596. DOI: https://doi.org/10.52403/ijrr.20211271 